\title{
Infusion of aerial parts of Salvia chudaei Batt. \& Trab. from Algeria: Chemical, toxicological and bioactivities characterization
}

\author{
Redouane Semaoui ${ }^{\text {a,b, }}{ }^{*}$, Saida Ouafi ${ }^{a}$, Susana Machado ${ }^{b}$, Lillian Barros ${ }^{c}$, Isabel C.F. \\ R. Ferreira ${ }^{\mathrm{c}}$, M. Beatriz P.P. Oliveira ${ }^{\mathrm{b}}$ \\ ${ }^{a}$ Research Laboratory on Arid Zones, Faculty of Biological Sciences, University of Sciences and Technology Houari Boumediene, BP 32, El Alia, Bab Ezzouar, 16111, \\ Algiers, Algeria \\ ${ }^{\mathrm{b}}$ REQUIMTE/LAQV, Department of Chemical Sciences, Faculty of Pharmacy, University of Porto, R. Jorge Viterbo Ferreira, 228 4050-313 Porto, Portugal

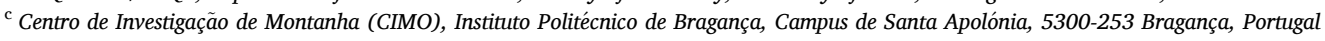

\begin{abstract}
A B S T R A C T
Ethnopharmacological relevance: Salvia chudaei Batt. \& Trab. from Algeria is traditionally used to relieve several dysfunctions, including inflammatory and pain-related situations.

Aim of the study: This work aimed to confirm scientifically the referred properties. For that, the phenolic composition and antioxidant activity were evaluated as well as acute toxicity, anti-inflammatory and analgesic effects of different doses of the infusion of $S$. chudaei aerial parts.

Materials and methods: Infusion of aerial parts of $S$. chudaei was prepared and screened for phenolic composition by generalized methods TPC and TFC then by LCDAD-ESI/MSn. DPPH and FRAP were used to evaluate antioxidant activity. Using mice, acute toxicity, anti-inflammatory by carrageenan-induced paw edema, and analgesic by acetic acid-induced writhing and formalin-induced pain activities were tested.

Results: The infusion showed $2018 \mathrm{mg}$ GAE/100g DW of phenolics and $1956 \mathrm{mg}$ ECE/100g DW of flavonoids. Phenolic profile by LC-DAD-ESI/MSn revealed the presence of ten compounds: syringic acid hexoside derivative, kaempferol-O-diglucuronide, kaempferol-O-deoxyhexoside-hexoside, kaempferol-O-glucuronide, apigenin-O-diglucuronide, caffeic acid, 4-O-caffeoylquinic acid, eriodictyol-O-glucuronide, rosmarinic acid hexoside, and rosmarinic acid. This acid was the major compound representing $54 \%$ of the total content of the identified compounds and an absolute content of $18 \mathrm{mg} / \mathrm{g}$ of extract. Additionally, the infusion exhibited a good antioxidant activity (DPPH: $81 \mu \mathrm{mol} \mathrm{TE} / \mathrm{g}$ DW, FRAP: $438 \mu \mathrm{mol}$ FSE/g DW). By oral administration to mice, the infusion showed a significant $(\mathrm{p}<0.05)$ dose-dependent reduction of carrageenan-induced inflammation and inhibition of formalin-induced pain (late and early phase) and acetic acid-induced writhing compared with the control. On the other hand, infusion up to $8 \mathrm{~g} / \mathrm{kg}$ b.w. showed no signs of toxicity or mortality.

Conclusion: This study reveals, for the first time, that the infusion of the aerial parts of $S$. chudaei is not toxic in a single dose and has remarkable antioxidant, antiinflammatory, and analgesic activities, supporting the use of this species in folk medicine.
\end{abstract}

\section{Introduction}

The use of traditional medicines, particularly herbal medicines, has been widely increasing during the recent decades (Popović et al., 2016). Since the old times, people used medicinal plants for healing and other health care, probably due to their wide availability, as well as the high cost and difficult access to drugs in some regions of the world. Their use represents also the preservation of the cultural heritage, considering the traditional medicine practice as a part of peoples culture (Van Wyk and Wink, 2018).

Lamiaceae (Labiatae) family that comprises 236 genera and about 6900-7200 species (Stevens, 2016; Tamokou et al., 2017) contains many species with medicinal virtues (Ruiz-Vargas et al., 2019; Saad et al., 2016; Sreeja et al., 2018). Salvia L. is the largest genus of this family (900-1000 species) (Walker et al., 2004); several Salvia species have very interesting pharmacological properties, namely antioxidant (Esmaeili and Sonboli, 2010), anti-diabetic (Flores-Bocanegra et al., 2017), analgesic (Simon-Arceo et al., 2017), in vitro/in vivo anti-inflammatory activity (Akram et al., 2015), and anti-Alzheimer effects (Senol et al., 2017), which in several cases are attributed to secondary metabolites, especially phenolic compounds.

Phenolic compounds include a multitude of molecules (e.g. flavonoids, phenolic acids, stilbenes, tannins, and lignans), responsible for the main organoleptic properties of plant derived-foods and beverages, and contributing also to the vegetables and fruits nutritional properties (Tapas et al., 2008). Simultaneously, phenolic compounds are getting a

\footnotetext{
* Corresponding author. Research Laboratory on Arid Zones, Faculty of Biological Sciences, University of Sciences and Technology Houari Boumediene, BP 32, El Alia, Bab Ezzouar, 16111, Algiers, Algeria.

E-mail addresses: re.dz@hotmail.fr, rseamoui@usthb.dz (R. Semaoui).
} 
large interest thanks to their association with many bioactivities, probably related to their antioxidant power (Shahidi and Yeo, 2018).

$S$. chudaei is an endemic plant of the central Sahara massif (Ozenda, 1991), known as Aouit in Tamahaq (indigenous language of the Touareg population in the South of Algeria) and as Tagrouft in Arabic. This plant is used to relieve numerous diseases and disorders such as ulcer, diarrhea, rheumatism, kidney diseases, dysmenorrhea, abdominal pain, spasms, urinary retention, urinary tract infection, and prostate pain, consumed as infusion, decoction, or powder (Hammiche and Maiza, 2006; Ramdane et al., 2015; Sekkoum et al., 2011). However, besides the use of this plant to relieve dysfunctions, no studies were carried out about its acute toxicity, anti-inflammatory activity, analgesic effect as well as its phenolic compound profile. Yet, some studies reported the composition of essential oil from aerial parts along with the antimicrobial and antioxidant activities of some organic extracts of $S$. chudaei (Hammoudi et al., 2017a; Krimat et al., 2015a, 2015b).

In order to confirm some of the reported healing virtues of $S$. chudaei infusion obtained from aerial parts, this research aimed to identify and quantify the molecules responsible for those medicinal benefits. To do that, different doses of infusion were tested in what concerns its toxicity, in vivo analgesic and anti-inflammatory effects, as well as its antioxidant activity, total phenolic and flavonoid contents, and phenolic profile by Liquid Chromatography coupled to Diode Array Detector and Electrospray Ionization tandem Mass Spectrometry (LC-DAD-ESI/MSn).

\section{Materials and methods}

\subsection{Plant material}

S. chudaei was harvested in January 2017 in the Ilamen station (longitude: $005^{\circ} 2930.6 \mathrm{E}$, latitude: $23^{\circ} 1426.9 \mathrm{~N}$, altitude: $2055 \mathrm{~m}$ ), located in the region of Tamanrasset in Southern Algeria. The authentication of the plant species was certified by the Higher National Agronomic School, El Harrach, Algiers, Algeria, according to Quezel and Santa (1963). A Standard specimen is conserved in the herbarium of Montpellier (voucher $\mathrm{N}^{\circ}$ : MPU 010317). The plant aerial parts were air shade dried, at room temperature $\left(22 \pm 2{ }^{\circ} \mathrm{C}\right)$, then ground in a mill to small particles for further use.

\subsection{Preparation of the infusion}

The infusion $(5 \% \mathrm{w} / \mathrm{v})$ was prepared by adding boiling deionized water to the sample powder and left to stand for $5 \mathrm{~min}$. Three independent extractions were prepared, the content filtered via Whatman paper $\mathrm{N}^{\circ}$. The prepared infusion was thereafter used in the assays. For the LC-DAD-ESI/MSn analysis, the infusion extract was firstly lyophilized then dissolved in methanol/water (80:20, v/v).

\subsection{Experimental animals}

20-30g Swiss albino mice (NMRI) purchased from the Pasteur Institute of Algiers (Algeria) were acclimatized for 2 weeks before experiments, housed at $24 \pm 1{ }^{\circ} \mathrm{C}, 50 \pm 5 \%$ humidity, and $12 / 12 \mathrm{~h}$ lightdark cycle. They were fed with rodent chow from the Animals Food National Office (ONAB) Bejaia, Algeria, and had free access to water. The animals were handled following the care and use of the laboratory animals guide (Council, 2010). All procedures involving animals were approved by the University Animal Experiment Ethics Committee (approval ref no. 162/2011/8).

\subsection{Acute oral toxicity}

The toxicity was evaluated in animals of both sexes, according to the Organization for Economic Co-operation and Development (OECD) guideline 423 with slight modifications (OECD, 2001). 3 groups of NMRI mice, consisting of 3 males and 3 females each, were used for this evaluation. Each group received $0.5 \mathrm{~mL}$ of $S$. chudaei infusion, in different doses as follows: group 1-2000 mg/kg b.w.; group 2-3000 $\mathrm{mg} / \mathrm{kg}$ b.w.; and group 3-5000 $\mathrm{mg} / \mathrm{kg}$ body weight (b.w.). After administration, the animals were carefully observed in the first $4 \mathrm{~h}$ for any abnormal behavior or toxicity sign and after, daily during 14 days to observe mortality.

\subsection{Analgesic activity}

To determine the analgesic activity two tests were evaluated: the Writhing and Formalin tests.

\subsubsection{Writhing test}

The writhing test using acetic acid (Liu et al., 2015) proceeded as follows. 5 groups, of 6 mice each, were used in this evaluation, the different groups receive orally as follows: group $1-0.5 \mathrm{~mL}$ saline solution; group $2-0.5 \mathrm{~mL}$ of paracetamol $\circledast$ at $100 \mathrm{mg} / \mathrm{kg} \mathrm{b.w.;} \mathrm{group} \mathrm{3,} \mathrm{4,}$ and $5-0.5 \mathrm{~mL}$ of $S$. chudaei infusion at 250,500 and $1000 \mathrm{mg} / \mathrm{kg}$ b.w., respectively. After $30 \mathrm{~min}$ they were intraperitoneally injected with 200 $\mu \mathrm{l}$ of $0.6 \%$ acetic acid. $5 \mathrm{~min}$ after, the abdominal constrictions number was counted for $15 \mathrm{~min}$. The results were expressed as protection percentage using the following formula:

Protection $\%=[(N C c-N C t) / N C c] x 100$

where NCc represents constrictions number in control (saline solution) and NCt the constrictions number in tested drug (paracetamol ${ }^{\circledR}$ and the infusion at different doses).

\subsubsection{Formalin test}

The antinociceptive activity of the sample extracts was assessed by the formalin test (Hunskaar et al., 1985). For that, 5 groups containing 5 mice each were formed. The different groups received per os: $1-0.5 \mathrm{~mL}$ of saline; $2-50 \mathrm{mg} / \mathrm{kg}$ b.w. paracetamol $\mathbb{R} ; 3-250 \mathrm{mg} / \mathrm{kg}$ b.w. of the infusion; $4-500 \mathrm{mg} / \mathrm{kg}$ b.w. of the infusion; $5-1000 \mathrm{mg} / \mathrm{kg}$ b.w. of the infusion. After $1 \mathrm{~h}, 20 \mu \mathrm{l}$ of formalin $(2.5 \%$ formaldehyde in $0.9 \% \mathrm{NaCl}$ saline) were subcutaneously injected into the right paw dorsal surface. Immediately, the licking and biting time of the injected paw was recorded for $5 \mathrm{~min}$ (early phase), and after 15-30 min (late phase). The protection percentage was calculated as follows:

Protection $\%=[(T c-T t) / T c] x 100$

in which, Tc represents the time of licking and biting in the control (saline solution), Tt the time of licking and biting in the tested drug (paracetamol $®$ and the infusion at different doses).

\subsection{Anti-inflammatory activity}

The evaluation of the anti-inflammatory activity was carried out by paw edema provocation with carrageenan (Levy, 1969). 1\% carrageenan in saline solution $(0.9 \% \mathrm{NaCl})$, was injected into the mice right hind paw plantar surface. In this experiment 5 groups of 6 mice each were used; the control group received $0.5 \mathrm{~mL}$ of saline solution; the reference group received $50 \mathrm{mg} / \mathrm{kg}$ b.w. of diclofenac; and the other three groups received 250,500, and $1000 \mathrm{mg} / \mathrm{kg}$ b.w. of $S$. chudaei infusion. The edema was induced after $30 \mathrm{~min}$ of the drug administration. $4 \mathrm{~h}$ later, mice were sacrificed by cervical dislocation and immediately both right and left hind paws were cut at the talocrural joint and weighted.

The results are expressed as inhibition edema percentage (IEP) using the formula below:

$I E P=[(E P c-E P t) / E P c] x 100$

in which, EP represents edema percentage in control (c, saline solution) and in tested drug ( $t$, diclofenac and infusion at different doses).

The edema percentage (EP) is calculated as follows: 
$E P=[(R P W-L P W) / L P W] x 100$

where RPW representing the right paw weight and LPW the left paw weight.

\subsection{Total phenolic content (TPC)}

Total phenolics were determined by spectrophotometry (BioTek Instruments, Inc.) (Alves et al., 2010) with some modifications. Briefly, 30 $\mu \mathrm{l}$ of the sample were mixed with $150 \mu \mathrm{l}$ of Folin-Ciocalteu reagent $(1: 10, \mathrm{v} / \mathrm{v})$ and $120 \mu \mathrm{l}$ of sodium carbonate $(7.5 \%, \mathrm{~m} / \mathrm{v})$. The mixture was then incubated during $15 \mathrm{~min}$ at $45^{\circ} \mathrm{C}$, followed by $30 \mathrm{~min}$ at room temperature, protected from light. The absorbance was measured at 765 $\mathrm{nm}$. The calibration curve was prepared with gallic acid $(5-80 \mathrm{mg} / \mathrm{L} ; \mathrm{r}=$ 0.9998) and the results expressed as $\mathrm{mg}$ of gallic acid equivalents/100g of sample dry weight (mg GAE/100g DW).

\subsection{Total flavonoid content (TFC)}

TFC were determined according to Costa et al. (2014). In brief, 100 $\mu \mathrm{L}$ of sample was mixed with $400 \mu \mathrm{L}$ distilled water and $30 \mu \mathrm{L} \mathrm{NaNO}_{2}$ $5 \%$; after $5 \mathrm{~min}$ at room temperature $30 \mu \mathrm{L} \mathrm{AlCl}_{3}$ were added to the mixture; 1 min after, $200 \mu \mathrm{L} \mathrm{NaOH} 1 \mathrm{M}$ and $250 \mu \mathrm{L}$ distilled water were added. Absorbance measurements were performed at $510 \mathrm{~nm}$. A calibration curve was prepared with epicatechin $(2.5-400 \mathrm{mg} / \mathrm{L} ; \mathrm{r}=$ 0.9946), and results expressed as $\mathrm{mg}$ of epicatechin equivalents $/ 100 \mathrm{~g}$ of sample dry weight (mg ECE/100g DW).

\subsection{Antioxidant activity}

\subsection{1. $D P P H^{\bullet}$ radical scavenging activity}

This method is based on the reduction of the free radical $\mathrm{DPPH}^{\bullet}(2,2$ diphenyl-1-picrylhydrazyl) by the antioxidants present in the infusion. The evaluation of the scavenging power was performed according to Costa et al. (2014), with some modifications. Briefly, $30 \mu \mathrm{l}$ of infusion was mixed with $270 \mu \mathrm{l}$ of $\mathrm{DPPH}^{\bullet}\left(6.0 \times 10^{-5} \mathrm{~mol} / \mathrm{L}\right.$ in ethanol $)$. The absorption decrease of $\mathrm{DPPH}^{\bullet}$ was measured at $525 \mathrm{~nm}$ in intervals of 2 $\mathrm{min}$, in order to observe the kinetics reaction. The reaction endpoint was reached in $20 \mathrm{~min}$. The results were expressed as $\mathrm{mg}$ trolox equivalent $/ \mathrm{g}$ of sample dry weight (mg TE/g DW) using a standard curve (5.62-75.87 $\mathrm{mg} / \mathrm{L}, \mathrm{r}=0.9978$ ).

\subsubsection{Ferric reducing antioxidant power (FRAP)}

The FRAP assay was carried out according to Costa et al. (2014). In brief, $35 \mu \mathrm{l}$ of sample was mixed with $265 \mu$ l of FRAP reagent $(0.3 \mathrm{M}$ acetate buffer, $10 \mathrm{mM}$ TPTZ solution, and $20 \mathrm{mM}$ of ferric chloride). The mixture was incubated for $30 \mathrm{~min}$ at $37{ }^{\circ} \mathrm{C}$ in dark. Absorbance was measured at $595 \mathrm{~nm}$. A calibration curve was prepared with ferrous sulfate (25-500 $\mu \mathrm{mol} / \mathrm{L} ; \mathrm{r}=0.9997)$ and the results expressed as $\mathrm{mg}$ of ferrous sulfate/g of sample DW (mg FSE/g DW).

\subsection{LC-DAD-ESI/MSn profiling of phenolic compounds}

LC-DAD-ESI/MSn (Dionex Ultimate 3000 UPLC, Thermo Scientific, San Jose, CA, USA) was used for the phenolic profile determination, according to Bessada et al. (2016) protocol. The obtained extract was lyophilized then dissolved in methanol:water $(80: 20, v / v)$ at $10 \mathrm{mg} / \mathrm{mL}$ concentration. Compounds were detected using a DAD with (370, 330, and $280 \mathrm{~nm}$ ) as favored wavelengths and MS in negative mode, via a Linear Ion Trap LTQ XL mass spectrometer (Thermo Finnigan, San Jose, CA, USA) coupled to ESI source. The compounds identification was based on their chromatographic behavior and UV-vis, and mass spectra, comparing with standards and reported data in literature via Xcalibur ${ }^{\circledR}$ data system (Thermo Finnigan, San Jose, CA, USA). The quantification was based on the UV-vis signal using the calibration curve for the available standards or the most similar for the non-available ones.
Values were expressed as $\mathrm{mg} / \mathrm{g}$ of extract.

\subsection{Statistical analysis}

Results were presented in mean \pm standard deviation. Comparisons between groups were performed by one-way ANOVA (analysis of variance) followed by post-hoc Tukey's HSD (Honestly Significant Difference) test. $\mathrm{p}<0.05$ was considered statistically significant. All statistics were carried out using R statistical software (version 3.6.0).

\section{Results and discussion}

\subsection{Phytochemical analysis}

In this work, we sought to investigate the antioxidant, antiinflammatory, and analgesic activities of $S$. chudaei infusion from the region of Tamanrasset (south of Algeria). It is well-known that establishing a correlation between phytochemical composition and potential biological activities has an essential role to figure out the potential compounds responsible for those activities. Hence, we have performed profiling and quantification of $S$. chudaei infusion phenolic compounds.

The infusion prepared at $5 \%$ rate yielded $15.48 \pm 0.14 \%(\mathrm{w} / \mathrm{w})$ of extract. Table 1 presents the Total Phenolic and Total Flavonoid contents determined spectrophotometrically. In what concerns TPC, S. chudaei infusion showed $2018.48 \pm 65.93 \mathrm{mg} \mathrm{GAE} / 100 \mathrm{~g}$ DW. Hammoudi et al. (2017b) reported for the same species $187.2 \pm 4.68$ and $292.1 \pm 3.81 \mathrm{mg} \mathrm{GAE} / 100 \mathrm{~g}$ DW for $80 \%$ ethanol-water and Soxhlet extracts, respectively. Moreover, $S$. chudaei infusion TPC, determined in this study, is superior or close regarding TPC of some other Salvia species infusions and aqueous extracts. This is the case of $S$. officinalis $431 \pm 37$ mg GAE/100g DW (Hernández-Saavedra et al., 2016), S. tomentosa $349.72 \pm 1.27$ and $S$. fruticosa $396.31 \pm 1.89 \mathrm{mg}$ GAE $/ 100 \mathrm{~g} \mathrm{DW}$ (Erdogan-Orhan et al., 2010), S. cadmica $940.93 \pm 6.97 \mathrm{mg} \mathrm{GAE} / 100 \mathrm{~g}$ DW (Kocak et al., 2016), and $S$. jurisicii $14.27 \pm 0.09 \mathrm{mg} \mathrm{GAE} / \mathrm{g}$ DW despite the $24 \mathrm{~h}$ maceration time and the use of ultrasound bath (Alimpić et al., 2017). Even when methanol-water 70\% and ethanol were used as solvents, which are known to have a high recovery, the phenolic compounds rate was $1981.56 \pm 32.13 \mathrm{mg} \mathrm{GAE} / 100 \mathrm{~g}$ (Poyraz et al., 2017). As exception, the aqueous maceration of $S$. officinalis during 24 h obtained $32 \mathrm{mg} \mathrm{GAE} / \mathrm{g}$ DW (Bahri et al., 2019), which was superior to the values from the presented work.

Concerning Total Flavonoids Content, $S$. chudaei infusion showed $1955.59 \pm 126.12 \mathrm{mg}$ ECE/100g DW. Several other Salvia infusions and aqueous extracts showed less TFC values, this is the case of: $S$. officinalis $892 \pm 26 \mathrm{mg}$ CE/100g DW (Hernández-Saavedra et al., 2016), S. fruticosa $107.14 \pm 2.47 \mathrm{mg} \mathrm{CE} / \mathrm{g} \mathrm{DE}$ (Altay, 2015), S. aramiensis $118.85 \pm 4.47 \mathrm{mg} \mathrm{CE} / \mathrm{g}$ DE (Karatoprak et al., 2020); methanolic extracts of S. sclarea, S. atropatana, S. ahendica, S. hydrangea, S. xanthocheila, S. macrosiphon, S. glutinosa, S. chloroleuca, and S. ceratophylla ranged from $2.2 \pm 0.2$ to $36.2 \pm 0.5 \mathrm{mg} \mathrm{CE} / \mathrm{g}$ DE (Loizzo et al., 2014), S. officinalis $11.2 \mathrm{mg} \mathrm{CE} / \mathrm{g} \mathrm{DE}$ (Ghorbanpour, 2015).

The comparison of TPC and TFC values of $S$. chudaei infusion with other reported results allows having an idea about the richness in phenolic compounds of $S$. chudaei infusion. Nevertheless, it is important to identify the type of phenolic compounds present in the sample, here identified by LC-DAD-ESI/MSn. Table 2 shows the results obtained with

Table 1

TPC, TFC, DPPH ${ }^{\bullet}$, and FRAP values of $S$. chudaei infusion.

\begin{tabular}{lll}
\hline Bioactive compounds & TPC mg GAE/100g DW & $2018.48 \pm 65.93$ \\
& TFC mg ECE/100g DW & $1955.59 \pm 126.12$ \\
Antioxidant activity & $\mathrm{DPPH}^{\bullet} \mu \mathrm{mol} \mathrm{TE} / \mathrm{g}$ DW & $81.31 \pm 7.79$ \\
& FRAP $\mu \mathrm{mol} \mathrm{FSE} / \mathrm{g}$ DW & $437.53 \pm 17.32$ \\
\hline
\end{tabular}

Mean \pm SD, $n=3$, mg GAE: gallic acid equivalent; ECE: epicatechin equivalent; TE: Trolox equivalent; FSE: ferrous sulfate equivalent; DW: dry weight. 
Table 2

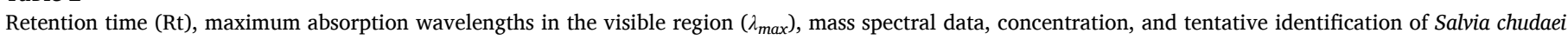
infusion phenolic compounds.

\begin{tabular}{|c|c|c|c|c|c|c|}
\hline Peak & Rt (min) & $\lambda_{\max }(\mathrm{nm})$ & {$[\mathrm{M}-\mathrm{H}]^{-}(m / z)$} & $\mathrm{MS}^{2}(m / z)$ & Tentative identification & Concentration $(\mathrm{mg} / \mathrm{g})$ of extract \\
\hline 1 & 6.59 & 321 & 353 & $191(11), 179(45), 173(100), 135(5)$ & 4-O-Caffeoylquinic acid (Cryptochlorogenic acid) & $1.783 \pm 0.005$ \\
\hline 2 & 7.53 & 283 & 403 & 241(70),197(100),179(5),135(5) & Syringic acid hexoside derivative & $0.51 \pm 0.02$ \\
\hline 3 & 10.07 & 323 & 179 & $135(100)$ & Caffeic acid & $0.74 \pm 0.03$ \\
\hline 4 & 13.66 & 340 & 637 & 285(100) & Kaempferol-O-diglucuronide & $1.42 \pm 0.03$ \\
\hline 5 & 15.45 & 285 & 595 & $287(100)$ & Eriodictyol-O-glucuronide & $0.81 \pm 0.02$ \\
\hline 6 & 16.2 & 330 & 621 & $269(100)$ & Apigenin-O-diglucuronide & $1.40 \pm 0.02$ \\
\hline 7 & 17.29 & 319 & 521 & $359(100), 197(5), 179(5), 161(5), 135(5)$ & Rosmarinic acid hexoside & $6.58 \pm 0.05$ \\
\hline 8 & 18.66 & 342 & 593 & $285(100)$ & Kaempferol-O-deoxyhexoside-hexoside & $1.235 \pm 0.003$ \\
\hline 9 & 18.95 & 341 & 461 & $285(100)$ & Kaempferol-O-glucuronide & $1.24 \pm 0.06$ \\
\hline \multirow[t]{4}{*}{10} & 21.97 & 328 & 359 & 197(100),179(34),161(19),135(5) & Rosmarinic acid & $18.3 \pm 0.5$ \\
\hline & & & & & TPA & $27.9 \pm 0.5$ \\
\hline & & & & & $\mathrm{TF}$ & $6.1 \pm 0.1$ \\
\hline & & & & & TPC & $34.0 \pm 0.5$ \\
\hline
\end{tabular}

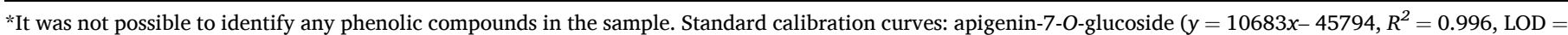

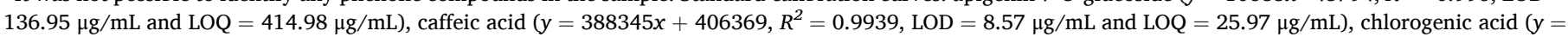

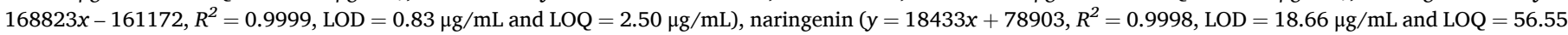

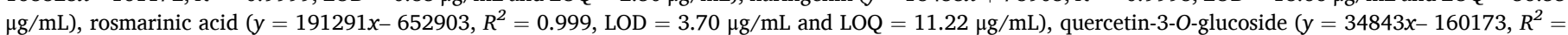

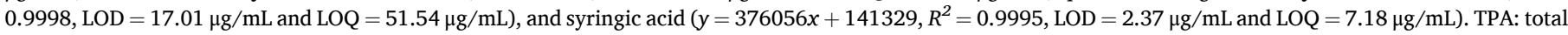
phenolic acids, TF: total flavonoids, TPC: total phenolic compounds.

such methodology.

The compounds identification was achieved through the UV-vis behavior and mass spectra fragmentation in negative ion mode, comparing with standards, when available, and Xcalibur ${ }^{\circledR}$ data system. According to literature review, no work on the profiling of phenolic compounds concerning $S$. chudaei from the Tamanrasset region (southern Algeria) or elsewhere, has been reported previously. Ten compounds from two classes, phenolic acids and flavonoids, were identified. Among the phenolic acids, one hydroxybenzoic acid (syringic acid hexoside derivative (2)) and four hydroxicinnamic acids (4-O-caffeoylquinic acid (1), caffeic acid (3), rosmarinic acid hexoside (7), and rosmarinic acid (10)) were detected. For the flavonoids class, five compounds were putatively identified, being three flavonols (kaempferol-O-diglucuronide (4), kaempferol-O-deoxyhexoside-hexoside (8), and kaempferolO-glucuronide (9)), one flavanone (eriodictyol-O-glucuronide (5)), and one flavone (apigenin-O-diglucuronide (6)).

Quantitatively, the rosmarinic acid was the major compound with an amount of $18.3 \pm 0.5 \mathrm{mg} / \mathrm{g}$ of extract, followed by another rosmarinic acid derivative, the rosmarinic acid hexoside with $6.58 \pm 0.05 \mathrm{mg} / \mathrm{g}$ of extract, representing together about $73 \%$ of identified phenolics. 4-Ocaffeoylquinic acid, kaempferol-O-diglucuronide, and apigenin-Odiglucuronide are present in considerable amounts of $1.783 \pm 0.005$, $1.42 \pm 0.03$, and $1.40 \pm 0.02 \mathrm{mg} / \mathrm{g}$ of extract, respectively. The less abundant were eriodictyol-O-glucuronide, caffeic acid, and syringic acid hexoside derivative with $0.81 \pm 0.02,0.74 \pm 0.03$, and $0.51 \pm 0.02 \mathrm{mg} /$ $\mathrm{g}$ of extract, respectively. The phenolic compounds extracted are almost all in the glycosylated form; glycosylation increases the solubility in water, the stability, and the promotion of the biological activity of various natural compounds including phenolics (Moon et al., 2017; Torres et al., 2011).

Several studies about phenolic compounds in Salvia species, using different extraction solvents (water, methanol, and ethanol), are in agreement with the present results. They reported rosmarinic acid as the dominant phenolic compound. This is the case of $S$. cadmica (Kocak et al., 2016), S. officinalis (Pedro et al., 2016), S. brachyantha and S. aethiopis (Tohma et al., 2016), and S. farinacea Var. Victoria Blue (Afonso et al., 2019). Nevertheless, some researchs have highlighted other abundant compounds than rosmarinic acid: luteolin-glucuronide in the infusion of $S$. officinalis (Martins et al., 2015; Schnitzler et al., 2008), and decoction and methanol/water extract of $S$. officinalis (Martins et al., 2015), kaempferol in an ethanolic extract of $S$. microstegia (Tohma et al., 2016). These molecules may function as genus markers of this species. Several factors can affect the chemical composition of plants, for example the harvesting season, geographical origin, and the extraction method (Moon et al., 2017). The reported findings indicate that $S$. chudaei can be a good source of rosmarinic and caffeic acid, as well as apigenin and kaempferol.

\subsection{Antioxidant activity}

Two colorimetric methods, $\mathrm{DPPH}^{\bullet}$ and FRAP, generally used to evaluate the antioxidant capacity of natural products, were performed with the same objective in this study. $\mathrm{DPPH}^{\bullet}$ assay is widely used to assess the ability of the compounds as free-radical scavengers or hydrogen donors to form stable non-radical $\mathrm{DPPH}^{\bullet}$ molecules. The results from the antioxidant activity evaluation are presented in Table 1 , with $S$. chudaei infusion $\mathrm{DPPH}^{\bullet}$ activity of $20.35 \pm 1.95 \mathrm{mg}$ TE/g DW $(81.31 \pm 7.79 \mu \mathrm{mol} \mathrm{TE} / \mathrm{g} \mathrm{DW})$. The $\mathrm{DPPH}^{\bullet}$ scavenging activity was higher than the reported by Kocak et al. (2016) for the infusion, and even for ethyl acetate and methanol extracts of $S$. Cadmica (40.51 \pm $0.05,5.93 \pm 0.13$, and $54.71 \pm 0.05 \mu \mathrm{mol} \mathrm{TE} / \mathrm{g} \mathrm{DW}$, respectively). Also, the reported results of Erdoğan et al. (2014) were inferior, for the methanolic extract of $S$. fruticosa leaves from three regions, with values ranging from $450.51 \pm 1.19$ to $287.57 \pm 2.16$ ( $\mu \mathrm{mol}$ TE/ $100 \mathrm{~g} \mathrm{DW})$. The determined value of $S$. chudaei infusion in this activity was higher than the ones determined in many plant infusions traditionally used in Andes/South America: Adesmia melanthes Phil. (1523 $\mu \mathrm{mol} \mathrm{TE} / \mathrm{L})$; Chuquiraga atacamensis K. (77 $\mu \mathrm{mol} \mathrm{TE} / \mathrm{L})$; Senecio nutans $(609 \mu \mathrm{mol}$ TE/L); Fabiana densa (1026 $\mu \mathrm{mol}$ TE/L); Fabiana squamata $(74 \mu \mathrm{mol}$ $\mathrm{TE} / \mathrm{L}) ;$ Lampaya medicinalis (1045 $\mu \mathrm{mol} \mathrm{TE} / \mathrm{L}) ;$ Azorella compacta (459 $\mu \mathrm{mol} \mathrm{TE} / \mathrm{L}) ;$ Opuntia ignescens $(6 \mu \mathrm{mol} \mathrm{TE} / \mathrm{L}) ;$ Baccharis tola $(67 \mu \mathrm{mol}$ TE/L); Parastrephia lepidophylla (265 $\mu \mathrm{mol}$ TE/L); Acantholippia deserticola $(222 \mu \mathrm{mol} \mathrm{TE} / \mathrm{L})$; and Parastrephia lucida (541 $\mu \mathrm{mol} \mathrm{TE} / \mathrm{L})$ (Rojo et al., 2009). However, S. officinalis from Brazilian market, extracted with a solvent solution of acetone/ultrapure water/glacial acetic acid (70:28:2, v/v) had higher DPPH activity $(2.59 \pm 0.17 \mathrm{~g}$ TE/100g DW) (Fernandes et al., 2016) than the infusion in evaluation.

The FRAP assay consists in TPTZ-Fe (III) complex reduction to TPTZ$\mathrm{Fe}$ (II) by the compounds present in tested samples. The reducing power is a useful determinant of potential antioxidant activity. S. chudaei infusion showed a value of $437.53 \pm 17.32 \mu \mathrm{mol} \mathrm{FSE} / \mathrm{g}$ DW, this value seems better than the ones previously reported by other authors. According to Grzegorczyk-Karolak and Kiss (2018) a FRAP activity between 890 and $1575 \mu \mathrm{mol} \mathrm{FSE} / \mathrm{g}$ extract were obtained for decoction, infusion, and ethanolic extracts of $S$. viridis. Alimpić et al. (2017) evaluated the decoction and ethanolic extract of $S$. jurisicii $(277.14 \pm 8.6$, 
and $279.44 \pm 8.45 \mu \mathrm{mol} \mathrm{FSE} / \mathrm{g}$ extract, respectively) obtained lower values than the reported in this work. Another study of nine Salvia species, using methanol as extraction solvent, showed a lower FRAP activity: $S$. sclarea L. $(160.1 \pm 1.5 \mu \mathrm{mol} \mathrm{FSE} / g$ extract); $S$. atropatana (Boiss.) Buhse Bunge (20.6 \pm 7.3$)$; S. ahendica (Boiss.) Buhse (8.9 \pm 4.1 ; S. hydrangea DC. (195.9 \pm 5.4); S. xanthocheila Boiss. ex Benth. (14.4 \pm 4.6); S. macrosiphon Boiss. (10.2 \pm 3.4$)$; S. glutinosa L. (422.0 \pm 9.8$)$; S. chloroleuca Rech.f. \& Aell. (12.9 \pm 0.8$)$ and S. ceratophylla L. (290.7 \pm $6.0 \mu \mathrm{mol} \mathrm{FSE} / \mathrm{g}$ extract) (Loizzo et al., 2014).

In both tests, $\mathrm{DPPH}^{\bullet}$ and FRAP, $S$. chudaei infusion exhibit excellent values for antioxidant activity, taking into account the reported results in the literature. It is also well-known that this feature has a strong correlation with TPC (Fernandes et al., 2016; Grzegorczyk-Karolak and Kiss, 2018; Kamatou et al., 2010), demonstrating the strong involvement of phenolics in antioxidant activity. Indeed, rosmarinic acid, non-exhaustively, could be responsible for the high antioxidant power of the sample. Rosmarinic acid extracted from Perilla frutescens leaves has displayed a higher $\mathrm{DPPH}^{\bullet}$ radical scavenging activity (SC50 $=5.5 \pm 0.2$ $\mu \mathrm{g} / \mathrm{mL})$ than $P$. frutescens leaves extract $(10.8 \pm 0.1 \mu \mathrm{g} / \mathrm{mL})$. Additionally, rosmarinic acid SC50 compared to standards was slightly close to that obtained by Trolox $(5.1 \pm 0.1 \mu \mathrm{g} / \mathrm{mL})$ and higher than that of butylated hydroxytoluene (BHT) $(6.6 \pm 0.3 \mu \mathrm{g} / \mathrm{mL})$ (Zhu et al., 2014). Moreover, rosmarinic acid showed the greatest activity potential among various phenolic acids tested in many antioxidant methods; caffeic acid has also shown an excellent antioxidant activity (Sevgi et al., 2015). Lu and Foo (2001) working on S. officinalis polyphenols have found that caffeic acid and rosmarinic acid derivatives exhibited potent antioxidant activity than flavone glycosides, and suggested that this strong activity could be due to their catechol moieties and conjugated unsaturation presence.

Reactive oxygen species (ROS) play a crucial role in the inflammatory response. They proceed as inflammatory mediators and signaling molecules produced by polymorphonuclear neutrophils (PMNs). Besides, reactive nitrogen species (RNS) can be rapidly formed by combination of nitrogen oxide (NO) and superoxide $\left(\mathrm{O}_{2}^{-}\right)$. Unfortunately, this reaction is 3-4 faster than the dismutation of superoxide by the superoxide dismutase (SOD) (Mittal et al., 2014). The unbalance between ROS/RNS production and deletion may probably damage biomolecules (DNA, lipids, amino acid ...), perturb cellular thiol levels, and deregulate cellular signaling pathways implicated in various diseases (Fransen et al., 2012; Mungli et al., 2009).

\subsection{Acute toxicity}

Table 3 displays the results (mortality and toxicity sign) of the determination of acute toxicity of the infusion of $S$. chudaei aerial parts. The different infusion tested doses $(2000,3000$, and $5000 \mathrm{mg} / \mathrm{kg}$ b.w.) did not show any toxicity sign (salivation, sleep, diarrhea, coma, etc.) in the first $4 \mathrm{~h}$ after oral administration. In the 14 days after, no mortality was observed for either male or female mice. This feature allows supposing the safety of $S$. chudaei infusion at the tested doses. Likewise, it is expected that LD50 (lethal dose causing 50\% of tested animals death) will be superior to $5000 \mathrm{mg} / \mathrm{kg}$ b.w., taking into account the absence of any toxicity sign/mortality. Nevertheless, it will be very

Table 3

Effect of $S$. chudaei infusion on acute oral toxicity in mice.

\begin{tabular}{llll}
\hline Dose $\mathrm{mg} / \mathrm{kg}$ b.w. & Animals & Mortality & Toxicity sign \\
\hline \multirow{2}{*}{ Control (saline) } & 3 male & - & - \\
\multirow{2}{*}{2000} & 3 female & - & - \\
& 3 male & - & - \\
3000 & 3 female & - & - \\
\multirow{2}{*}{5000} & 3 male & - & - \\
& 3 female & - & - \\
& 3 male & - & - \\
\hline
\end{tabular}

interesting to complete this test with a sub-acute oral toxicity test including biochemical and histological studies.

\subsection{Anti-inflammatory activity}

The anti-inflammatory effect of $S$. chudaei infusion was evaluated via carrageenan test, one of the most popular tests to screen the antiinflammatory properties of drugs and plant extracts. Table 4 shows the effect of three doses of $S$. chudaei infusion orally administered on mice paw induced inflammation. The doses $(250,500$, and $1000 \mathrm{mg} / \mathrm{kg}$ b.w.) of $S$. chudaei infusion and diclofenac ${ }^{\circledR}(50 \mathrm{mg} / \mathrm{kg}$ b.w. $)$ reduced significantly $(\mathrm{p}<0.001)$ the paw edema after $4 \mathrm{~h}$ of administration, comparing to the control. The lower edema percentage was obtained with the more concentrated infusion $(1000 \mathrm{mg} / \mathrm{kg}$ b.w.) with an inhibition percentage of $58 \%$, showing a strong anti-inflammatory effect. This effect was better than the effect obtained with diclofenac ${ }^{\circledR}(50 \mathrm{mg}$ / $\mathrm{kg}$ b.w.) that allowed an inhibition percentage of 53\%. The other assayed infusion doses (250 and $500 \mathrm{mg} / \mathrm{kg}$ b.w.) allowed obtaining lower percentages but not so far from the mentioned values (45 and $48 \%$, respectively). Many Salvia species have been screened for their anti-inflammatory activity (Akram et al., 2015; Kamatou et al., 2010). Choi et al. (2018) reported that some caffeic acid derivatives, especially rosmarinic acid methyl ester, extracted from $S$. miltiorrhiza exhibit potent anti-inflammatory effects through the inhibition of inflammatory mediators (COX-2: cyclooxygenase-2, NO: nitric oxide, and iNOS: inducible nitric oxide synthase) and the induction of HO-1 (heme oxygenase-1) which have for mission to inhibit the oxidative stress. On the other hand, Kamatou et al. (2010) tested the anti-inflammatory potential of sixteen Salvia species, reporting a poor inhibition of the 5-lipoxygenase enzyme (IC50 $>100 \mu \mathrm{g} / \mathrm{mL}$ ), with exception of one species that displayed a moderate inhibition. The administration of Rosmarinus officinalis extract and its rosmarinic acid in similar dose (25 $\mathrm{mg} / \mathrm{kg}$ b.w.) resulted the same paw edema inhibition of about $60 \%$ volume reduction compared with control (Rocha et al., 2015).

Taking into account the results of the phytochemical analysis performed in this study revealing the presence of rosmarinic acid as the main compound, and its described anti-inflammatory and antioxidant potential, it is expectable the ability of $S$. chudaei infusion to inhibit paw edema. This activity has rosmarinic acid as the responsible, probably due to its action on the COX-2 inhibition pathway. Many studies involve the flavonoids in the in vitro and in vivo anti-inflammatory properties. This is the case of apigenin, a compound with a significant presence in the studied sample, that is linked to its ability to inhibit cyclooxygenase and lipoxygenase enzymes (Kim et al., 2004; Narayana et al., 2001).

\subsection{Analgesic tests}

\subsubsection{Acetic acid-induced writhing test}

The analgesic effect of $S$. chudaei infusion was evaluated by the acetic acid test and Table 5 summarizes the obtained results. All tested doses (250, 500, and $1000 \mathrm{mg} / \mathrm{kg}$ b.w.) showed highly significant $(\mathrm{p}<0.001)$

Table 4

Effect of $S$. chudaei infusion on carrageenan-induced paw edema in mice.

\begin{tabular}{llll}
\hline Group (n=5) & $\begin{array}{l}\text { Dose }(\mathrm{mg} / \mathrm{kg} \text { b. } \\
\text { w.) }\end{array}$ & Edema (\%) & $\begin{array}{l}\text { Inhibition percentage } \\
(\%)\end{array}$ \\
\hline $\begin{array}{c}\text { Control } \\
\text { (saline) }\end{array}$ & $0.5(\mathrm{~mL})$ & $42.00 \pm 2.12 \mathrm{a}$ & - \\
Diclofenac & & & \\
& 50 & $\begin{array}{l}19.79 \pm 1.15 \\
\text { bd }\end{array}$ & 52.91 \\
Infusion & 250 & $23.20 \pm 1.11 \mathrm{c}$ & 44.79 \\
& 500 & $21.64 \pm 1.61$ & 48.51 \\
& & bc & \\
& 1000 & $17.55 \pm 1.48 \mathrm{~d}$ & 58.25 \\
\hline
\end{tabular}

Mean \pm SD, different letters indicate statistically significant differences between groups $(\mathrm{p}<0.05)$. 
Table 5

Effect of $S$. chudaei infusion on constrictions number of acetic acid-induced writhing test in mice.

\begin{tabular}{llll}
\hline Group (n=6) & $\begin{array}{l}\text { Dose }(\mathrm{mg} / \mathrm{kg} \\
\text { b.w.) }\end{array}$ & $\begin{array}{l}\text { Mean of constrictions } \\
\text { number }\end{array}$ & $\begin{array}{l}\text { Inhibition } \\
\text { percentage (\%) }\end{array}$ \\
\hline $\begin{array}{c}\text { Control } \\
\quad \text { saline) }\end{array}$ & $0.5 \mathrm{~mL}$ & $48.83 \pm 3.43 \mathrm{a}$ & - \\
Paracetamol & & & \\
Infusion & 100 & $24.00 \pm 3.16 \mathrm{bc}$ & 50.85 \\
& 250 & $26.67 \pm 1.50 \mathrm{~b}$ & 45.38 \\
& 500 & $21.67 \pm 2.94 \mathrm{c}$ & 55.63 \\
& 1000 & $15.00 \pm 1.67 \mathrm{~d}$ & 69.28 \\
\hline
\end{tabular}

Mean \pm SD, different letters indicate statistically significant differences between groups $(\mathrm{p}<0.05)$.

reduction of abdominal constrictions, comparing to the control. The decreasing number of constrictions is dependent of the tested dose, meaning that the highest dose $(1000 \mathrm{mg} / \mathrm{kg}$ b.w.) has the least number of constrictions (15, with an inhibition percentage of $69 \%$ ). Paraceta$\mathrm{mol} \circledast 100 \mathrm{mg} / \mathrm{kg}$ b.w. showed also a highly significant $(\mathrm{p}<0.001)$ reduction regarding the control ( $51 \%$ with 24 constrictions). It is worth noting that the infusion doses 500 and $1000 \mathrm{mg} / \mathrm{kg}$ b.w. exhibited higher protection percentages ( $56 \%$ and $69 \%$, respectively) than paracetamol $\mathbb{}(51 \%)$. The less concentrated infusion sample presented inhibition percentage slightly lower (45.38) than paracetamol ${ }^{\circledR}$. Nevertheless, the presented values give to $S$. chudaei infusion a potential analgesic effect.

In the acetic acid test, after intraperitoneal injection of the acid, an increase in the number of polymorphonuclear neutrophils into the peritoneal fluid was detected; this may raise the release of several inflammatory mediators, leading to the inflammatory pain in the inflammation site through nociceptive neurons stimulation. The acetic acid activates directly visceral and somatic nociceptors, as a general (nonselective) nociceptive model. It is a sensitive test to evaluate the peripheral analgesic action of drugs (Abbate et al., 1990; Le Bars et al., 2001; Satyanarayana et al., 2004).

\subsubsection{Formalin test}

The antinociceptive action of $S$. chudaei infusion was determined by measuring the spent time in licking/biting mice paw, after formalin injection, and the results are displayed in Table 6. Three doses $(250,500$, and $1000 \mathrm{mg} / \mathrm{kg}$ b.w.) of infusion were used to evaluate the neurogenic (early) and inflammatory (late) phases. In both phases, the licking/ biting time was dose-dependent, decreasing with the dose increasing. In the early phase, the licking/biting time of the tested doses decreased significantly, comparing to the control (Table 6). The highest protection percentage was exhibited by the $1000 \mathrm{mg} / \mathrm{kg}$ b.w. dose (61\%). This value is near to the one presented by paracetamol ${ }^{\circledR} 50 \mathrm{mg} / \mathrm{kg}$ b.w. $(63 \%)$. In the late phase, a significant decrease in licking/biting time was also observed in all tested doses, comparatively to control, and in a similar way as described for the early phase. The $1000 \mathrm{mg} / \mathrm{kg}$ b.w. infusion dose showed a protection percentage of $58 \%$, lower than the paracetamol $50 \mathrm{mg} / \mathrm{kg}$ b.w. protection percentage (65\%) but an interesting antinociceptive action.

In the formalin test, there is a biphasic nociceptive response: an immediate and intense response characterized by direct activation of sensory fibers (early phase: $0-5 \mathrm{~min}$ ); a prolonged tonic response phase related to the functional changes in the spinal cords dorsal horn and the production and release of numerous inflammatory mediators in the peripheral tissue (late phase: 15-30 min) (Dubuisson and Dennis, 1977; Tjølsen et al., 1992). In general, drugs acting on the central system inhibit these phases, whereas the peripherally acting ones inhibit only the early phase.

The results obtained from these analgesic tests suggest that $S$. chudaei infusion has peripheral and central analgesic activity. Rosmarinic acid may be the responsible, once it was proven to attenuate both central and peripheral pain involving opioid receptors. It may reduce the liberation
Table 6

Effect of $S$. chudaei infusion on early and late phase of the formalin test in mice.

\begin{tabular}{|c|c|c|c|c|c|}
\hline \multirow[t]{2}{*}{ Group $(n=5)$} & \multirow{2}{*}{$\begin{array}{l}\text { Dose } \\
\text { mg/ } \\
\text { kg b. } \\
\text { w. }\end{array}$} & \multicolumn{2}{|c|}{ Early phase } & \multicolumn{2}{|c|}{ Late phase } \\
\hline & & $\begin{array}{l}\text { Liking/ } \\
\text { biting } \\
\text { time (s) }\end{array}$ & $\begin{array}{l}\text { Inhibition } \\
\text { percentage } \\
(\%)\end{array}$ & $\begin{array}{l}\text { Licking/ } \\
\text { biting } \\
\text { time (s) }\end{array}$ & $\begin{array}{l}\text { Inhibition } \\
\text { percentage } \\
(\%)\end{array}$ \\
\hline $\begin{array}{l}\text { Control } \\
\text { (saline) }\end{array}$ & $\begin{array}{l}0.5 \\
\mathrm{~mL}\end{array}$ & $\begin{array}{l}84.60 \pm \\
3.21 \mathrm{a}\end{array}$ & - & $\begin{array}{l}66.00 \pm \\
2.91 \mathrm{a}\end{array}$ & - \\
\hline Paracetamol ${ }^{\circledR}$ & 50 & $\begin{array}{l}31.00 \pm \\
2.25 \mathrm{~b}\end{array}$ & 63.35 & $\begin{array}{l}22.80 \pm \\
3.03 \mathrm{~b}\end{array}$ & 65.45 \\
\hline \multirow[t]{3}{*}{ Infusion } & 250 & $\begin{array}{l}44.40 \pm \\
2.41 \mathrm{c}\end{array}$ & 47.51 & $\begin{array}{l}37.00 \pm \\
1.58 \mathrm{c}\end{array}$ & 43.93 \\
\hline & 500 & $\begin{array}{l}39.00 \mathrm{t} \\
3.39 \mathrm{~cd}\end{array}$ & 53.90 & $\begin{array}{l}29.60 \pm \\
2.07 \mathrm{~d}\end{array}$ & 55.15 \\
\hline & 1000 & $\begin{array}{l}33.20 \pm \\
3.63 \text { bd }\end{array}$ & 60.75 & $\begin{array}{l}27.60 \pm \\
1.92 \mathrm{~d}\end{array}$ & 58.18 \\
\hline
\end{tabular}

Mean \pm SD, different letters indicate statistically significant differences between groups $(\mathrm{p}<0.05)$.

of inflammatory mediators (see anti-inflammatory part (3.4.)) or directly block receptors (Boonyarikpunchai et al., 2014). Moreover, rosmarinic acid orally administered produces a significant and dose-dependent nociceptive response inhibition in mice paw glutamate-induced nociception (Guginski et al., 2009). In addition, rosmarinic acid showed a decrease of inflammatory and oxidative markers (COX-2, PGE-2, NO, IL-1 $\beta$ ) in the spinal cord levels (Rahbardar et al., 2017).

Another study reported rosmarinic acid pain reduction only in the formalin test late phase (Falcão et al., 2016). Furthermore, kaempferol glycosides may display also an analgesic effect. After oral administration, they showed a potent analgesic and anti-inflammatory effect in mice (De Melo et al., 2009).

\section{Conclusions}

This is the first work about phenolic compounds composition, antiinflammatory, and analgesic effect of the infusion of Salvia chudaei Batt. \& Trab. The infusion has a remarkable antioxidant and antiinflammatory activities, with analgesic effects in both central and peripheral models. The rosmarinic acid seems to be the main compound justifying such effects. Thus, the biological activities of $S$. chudaei aerial parts infusion may be due to the ability of phenolic compounds to inhibit inflammatory mediator generation, to act as radical scavenging, and to block directly the nociceptive receptors. The results of this study support the folk use of Salvia chudaei to treat inflammation and pain. However, more tests are needed to completely understand the mechanisms of action.

\section{Author contributions}

All authors were involved in the writing and design of this study. R.S. performed experiments and drafted the manuscript. S.M. contributed to TPC, TFC, DPPH ${ }^{\bullet}$, and FRAP experiments. L.B. and I.C.F.R.F. provided LC-MS analysis. S.O. and M.B.P.P.O. designed and supervised the study, and revised the manuscript. All authors read and approved the final version of the manuscript.

\section{Declaration of competing interest}

The authors declare that they have no known competing financial interests or personal relationships that could have appeared to influence the work reported in this paper.

\section{Acknowledgements}

We thank the University of Porto for receiving R.S. and the MARE 
NOSTRUM 2017-2019 project allowing this mobility. This work was supported by AgriFood XXI I\&D\&I project (NORTE-01-0145-FEDER000041) co-financed by ERDF through NORTE 2020 (Programa Operacional Regional do Norte 2014/2020), by the UIDB/50006/2020 project with funding from FCT/MCTES through Portuguese funds, by the Foundation for Science and Technology (FCT, Portugal) through national funds FCT/MCTES to CIMO (UIDB/00690/2020), and by the Ministry of Higher Education and Scientific Research (MESRS) (Algeria).

\section{References}

Abbate, R., Gori, A., Pinto, S., Attanasio, M., Paniccia, R., Coppo, M., Castellani, S., Giusti, B., Boddi, M., Serneri, G.N., 1990. Cyclooxygenase and lipoxygenase metabolite synthesis by polymorphonuclear neutrophils: in vitro effect of dipyrone Prostag1. Leukot. Essent. Fat. Acids 41 (2), 89-93.

Afonso, A.F., Pereira, O.R., Fernandes, Â.S., Calhelha, R.C., Silva, A., Ferreira, I.C., Cardoso, S.M., 2019. The health-benefits and phytochemical profile of Salvia apiana and Salvia farinacea var. Victoria blue decoctions. Antioxidants 8 (8), 241.

Akram, M., Syed, A.S., Kim, K.A., Lee, J.S., Chang, S.Y., Kim, C.Y., Bae, O.N., 2015. Heme oxygenase 1-mediated novel anti-inflammatory activities of Salvia plebeia and its active components. J. Ethnopharmacol. 174, 322-330.

Alimpić, A., Knežević, A., Šavikin, K., Ćurčić, M., Veličković, D., Stević, T., Matevski, V., Stajić, M., Marković, S., Marin, P., 2017. Composition and biological activities of different extracts of Salvia jurisicii, a rare and endemic Macedonian species. Plant Biosystems-An International Journal Dealing with all Aspects of Plant Biology 151 (6), 1002-1011.

Altay, A., 2015. Antioxidant and Cytotoxic Properties of Salvia Fruticosa M. And its Effects on Gene Expressions of Some CYP450 and Antioxidant Enzymes in HT-29 Cell Line.

Alves, R.C., Costa, A.S., Jerez, M.a., Casal, S., Sineiro, J., , Núnẽz, M.a.J., Oliveira, B., 2010. Antiradical activity, phenolics profile, and hydroxymethylfurfural in espresso coffee: influence of technological factors. J. Agric. Food Chem. 58 (23), 12221-12229.

Bahri, S., Ben Ali, R., Abdennabi, R., Ben Said, D., Mlika, M., Ben Fradj, M.K., El May, M. V., Jameleddine, S.B.K., 2019. Comparison of the protective effect of Salvia officinalis and Rosmarinus officinalis infusions against hepatic damage induced by hypotermic-ischemia in wistar rats. Nutr. Canc. 1-10.

Bessada, S.M., Barreira, J.C., Barros, L., Ferreira, I.C., Oliveira, M.B.P., 2016. Phenolic profile and antioxidant activity of Coleostephus myconis (L.) Rchb. f.: an underexploited and highly disseminated species. Ind. Crop. Prod. 89, 45-51.

Boonyarikpunchai, W., Sukrong, S., Towiwat, P., 2014. Antinociceptive and antiinflammatory effects of rosmarinic acid isolated from Thunbergia laurifolia Lindl. Pharmacol., Biochem. Behav. 124, 67-73.

Choi, H.G., Tran, P.T., Lee, J.-H., Min, B.S., Kim, J.A., 2018. Anti-inflammatory activity of caffeic acid derivatives isolated from the roots of Salvia miltiorrhiza Bunge. Arch Pharm. Res. (Seoul) 41 (1), 64-70.

Costa, A.S., Alves, R.C., Vinha, A.F., Barreira, S.V., Nunes, M.A., Cunha, L.M., Oliveira, M.B.P., 2014. Optimization of antioxidants extraction from coffee silverskin, a roasting by-product, having in view a sustainable process. Ind. Crop. Prod. 53, 350-357.

Council, N.R., 2010. Guide for the Care and Use of Laboratory Animals. National Academies Press.

De Melo, G.O., Malvar, D.d.C., Vanderlinde, F.A., Rocha, F.F., Pires, P.A., Costa, E.A., de Matos, L.G., Kaiser, C.R., Costa, S.S., 2009. Antinociceptive and anti-inflammatory kaempferol glycosides from Sedum dendroideum. J. Ethnopharmacol. 124 (2), 228-232.

Dubuisson, D., Dennis, S.G., 1977. The formalin test: a quantitative study of the analgesic effects of morphine, meperidine, and brain stem stimulation in rats and cats. Pain 4, 161-174.

Erdogan-Orhan, I., Baki, E., Șenol, S., Yilmaz, G., 2010. Sage-called plant species sold in Turkey and their antioxidant activities. J. Serb. Chem. Soc. 75 (11), 1491-1501.

Erdoğan, S.S., , Karik, Ü., Başer, K.H.C., 2014. The determination of antioxidant activity of some sage populations of in the Marmara region. Türk Tarım ve Doğa Bilimleri Dergisi 1 (Özel Say1-2), 1877-1882.

Esmaeili, M.A., Sonboli, A., 2010. Antioxidant, free radical scavenging activities of Salvia brachyantha and its protective effect against oxidative cardiac cell injury. Food Chem. Toxicol. : an international journal published for the British Industrial Biological Research Association 48 (3), 846-853.

Falcão, R.E., Souza, S.A.d., Camara, C.A., Quintans, J.S., Santos, P.L., Correia, M.T.S., Silva, T., Lima, A.A., Quintans-Júnior, L.J., Guimarães, A.G., 2016. Evaluation of the orofacial antinociceptive profile of the ethyl acetate fraction and its major constituent, rosmarinic acid, from the leaves of Hyptis pectinata on rodents. Revista Brasileira de Farmacognosia 26 (2), 203-208.

Fernandes, R.d.P.P., Trindade, M.A., Tonin, F.G., Lima, C.G.d., Pugine, S.M.P. Munekata, P.E.S., Lorenzo, J., De Melo, M., 2016. Evaluation of antioxidant capacity of 13 plant extracts by three different methods: cluster analyses applied for selection of the natural extracts with higher antioxidant capacity to replace synthetic antioxidant in lamb burgers. J. Food Sci. Technol. 53 (1), 451-460.

Flores-Bocanegra, L., González-Andrade, M., Bye, R., Linares, E., Mata, R., 2017. $\alpha$-Glucosidase inhibitors from Salvia circinata. J. Nat. Prod. 80 (5), 1584-1593.

Fransen, M., Nordgren, M., Wang, B., Apanasets, O., 2012. Role of peroxisomes in ROS/ RNS-metabolism: implications for human disease. Biochim. Biophys. Acta 1822 (9), 1363-1373.
Ghorbanpour, M., 2015. Major essential oil constituents, total phenolics and flavonoids content and antioxidant activity of Salvia officinalis plant in response to nanotitanium dioxide. Indian J. Plant Physiol. 20 (3), 249-256.

Grzegorczyk-Karolak, I., Kiss, A.K., 2018. Determination of the phenolic profile and antioxidant properties of Salvia viridis L. shoots: a comparison of aqueous and hydroethanolic extracts. Molecules 23 (6), 1468.

Guginski, G., Luiz, A.P., Silva, M.D., Massaro, M., Martins, D.F., Chaves, J., Mattos, R.W., Silveira, D., Ferreira, V.M., Calixto, J.B., 2009. Mechanisms involved in the antinociception caused by ethanolic extract obtained from the leaves of Melissa officinalis (lemon balm) in mice. Pharmacol., Biochem. Behav. 93 (1), 10-16.

Hammiche, V., Maiza, K., 2006. Traditional medicine in central Sahara: pharmacopoeia of tassili N'ajjer. J. Ethnopharmacol. 105 (3), 358-367.

Hammoudi, R., Karima, D., Tlili, M.L., Khenfer, S., Medjouel, M., Hadj Mahammed, M., 2017a. Biological activities of phenolic extracts of a medicinal plant, endemic to the Algerian Sahara: Salvia chudaei Batt. \& Trab. Int. J. Biosci. 11 (3), 108-115.

Hammoudi, R., Khenfer, S., Medjouel, M., Tlili, M.L., Mahammed, M.H., 2017b. Optimization of extraction conditions for phenolic compounds from Salvia chudaei. Leban. Sci. J. 18 (2), 234.

Hernández-Saavedra, D., Pérez-Ramírez, I.F., Ramos-Gómez, M., Mendoza-Díaz, S., Loarca-Pina, G., Reynoso-Camacho, R., 2016. Phytochemical characterization and effect of Calendula officinalis, Hypericum perforatum, and Salvia officinalis infusions on obesity-associated cardiovascular risk. Med. Chem. Res. 25 (1), $163-172$.

Hunskaar, S., Fasmer, O.B., Hole, K., 1985. Formalin test in mice, a useful technique for evaluating mild analgesics. J. Neurosci. Methods 14 (1), 69-76.

Kamatou, G.P., Viljoen, A.M., Steenkamp, P., 2010. Antioxidant, antiinflammatory activities and HPLC analysis of South African Salvia species. Food Chem. 119 (2), 684-688.

Karatoprak, G.Ş., , Yücel, Ç., Göger, F., Sobarzo-Sánchez, E., Akkol, E.K., 2020. Potential antioxidant and enzyme inhibitory effects of nanoliposomal formulation prepared from Salvia aramiensis Rech. f. Extract. Antioxidants 9 (4), 293.

Kim, H.P., Son, K.H., Chang, H.W., Kang, S.S., 2004. Anti-inflammatory plant flavonoids and cellular action mechanisms. J. Pharmacol. Sci. 0411110005-0411110005.

Kocak, M.S., Sarikurkcu, C., Cengiz, M., Kocak, S., Uren, M.C., Tepe, B., 2016. Salvia cadmica: phenolic composition and biological activity. Ind. Crop. Prod. 85, 204-212.

Krimat, S., Dob, T., Toumi, M., Kesouri, A., Noasri, A., 2015a. Assessment of phytochemicals, antioxidant, antimicrobial and cytotoxic properties of Salvia chudaei Batt. et Trab. endemic medicinal plant from Algeria. J. Mater. Environ. Sci. 6 (1), 70-78.

Krimat, S., Dob, T., Toumi, M., Lamari, L., Dahmane, D., 2015b. Chemical composition, antimicrobial and antioxidant activities of essential oil of Salvia chudaei Batt. et Trab. endemic plant from Algeria. J. Essent. Oil Res. 27 (5), 447-453.

Le Bars, D., Gozariu, M., Cadden, S.W., 2001. Animal models of nociception. Pharmacol. Rev. 53 (4), 597-652.

Levy, L., 1969. Carrageenan paw edema in the mouse. Life Sci. 8 (11), 601-606.

Liu, X., Yang, B., Zhang, L., Lu, Y., Gong, M., Tian, J., 2015. An in vivo and in vitro assessment of the anti-inflammatory, antinociceptive, and immunomodulatory activities of Clematis terniflora DC. extract, participation of aurantiamide acetate. J. Ethnopharmacol. 169, 287-294.

Loizzo, M.R., Abouali, M., Salehi, P., Sonboli, A., Kanani, M., Menichini, F., Tundis, R., 2014. In vitro antioxidant and antiproliferative activities of nine Salvia species. Nat. Prod. Res. 28 (24), 2278-2285.

Lu, Y., Foo, L.Y., 2001. Antioxidant activities of polyphenols from sage (Salvia officinalis). Food Chem. 75 (2), 197-202.

Martins, N., Barros, L., Santos-Buelga, C., Henriques, M., Silva, S., Ferreira, I.C., 2015 Evaluation of bioactive properties and phenolic compounds in different extracts prepared from Salvia officinalis L. Food Chem. 170, 378-385.

Mittal, M., Siddiqui, M.R., Tran, K., Reddy, S.P., Malik, A.B., 2014. Reactive oxygen species in inflammation and tissue injury. Antioxidants Redox Signal. 20 (7), 1126-1167.

Moon, K.-O., Park, S., Joo, M., Ha, K.-T., Baek, N.-I., Park, C.-S., Cha, J., 2017. Glycosylation enhances the physicochemical properties of caffeic acid phenethyl ester. J. Microbiol. Biotechnol. 27 (11), 1916-1924.

Mungli, P., Shetty, M.S., Tilak, P., Anwar, N., 2009. Total thiols: biomedical importance and their alteration in various disorders. Online J. Health Allied Sci. 8 (2).

Narayana, K.R., Reddy, M.S., Chaluvadi, M., Krishna, D., 2001. Bioflavonoids classification, pharmacological, biochemical effects and therapeutic potential. Indian J. Pharmacol. 33 (1), 2-16.

OECD, 2001. The OECD Guideline for Testing of Chemical: 423 Acute Oral Toxicity. OECD Paris.

Ozenda, P., 1991. Les relations biogéographiques des montagnes sahariennes avec la région méditerranéenne. Rev. Géogr. Alp. 79 (1), 43-53.

Pedro, D.F., Ramos, A.A., Lima, C.F., Baltazar, F., Pereira-Wilson, C., 2016. Colon cancer chemoprevention by sage tea drinking: decreased DNA damage and cell proliferation. Phytother Res. 30 (2), 298-305.

Popović, Z., Matić, R., Bojović, S., Stefanović, M., Vidaković, V., 2016. Ethnobotany and herbal medicine in modern complementary and alternative medicine: an overview of publications in the field of I\&C medicine 2001-2013. J. Ethnopharmacol. 181, 182-192.

Poyraz, İ.E., Çiftçi, G.A., Öztürk, N., 2017. Phenolic contents, in vitro antioxidant and cytotoxicity activities of Salvia aethiopis L. And S. Ceratophylla L.(Lamiaceae). Record Nat. Prod. 11 (4).

Quezel, P., Santa, S., 1963. Nouvelle flore de l'Algérie et des régions désertiques méridionales.

Rahbardar, M.G., Amin, B., Mehri, S., Mirnajafi-Zadeh, S.J., Hosseinzadeh, H., 2017. Anti-inflammatory effects of ethanolic extract of Rosmarinus officinalis L. and 
rosmarinic acid in a rat model of neuropathic pain. Biomed. Pharmacother. 86, 441-449.

Ramdane, F., Hadj Mahammed, M., Didi Ould Hadj, M., Chanai, A., Hammoudi, R., Hillali, N., Mesrouk, H., Bouafia, I., Bahaz, C., 2015. Ethnobotanical study of some medicinal plants from Hoggar, Algeria. J. Med. Plants Res. 9 (30), 820-827.

Rocha, J., Eduardo-Figueira, M., Barateiro, A., Fernandes, A., Brites, D., Bronze, R., Duarte, C.M., Serra, A.T., Pinto, R., Freitas, M., 2015. Anti-inflammatory effect of rosmarinic acid and an extract of Rosmarinus officinalis in rat models of local and systemic inflammation. Basic Clin. Pharmacol. Toxicol. 116 (5), 398-413.

Rojo, L.E., Benites, J., Lopez, J., Rojas, M., Diaz, P., Ordonez, J., Pastene, E., 2009. Antioxidant capacity and polyphenolic content of twelve traditionally used herbal medicinal infusions from the South American Andes. Bol. Latinoam. Caribe Plantas Med. Aromat. 8 (6), 498-508.

Ruiz-Vargas, J.A., Morales-Ferra, D.L., Ramírez-Ávila, G., Zamilpa, A., Negrete-León, E., Acevedo-Fernández, J.J., Peña-Rodríguez, L.M., 2019. $\alpha$-Glucosidase inhibitory activity and in vivo antihyperglycemic effect of secondary metabolites from the leaf infusion of Ocimum campechianum mill. J. Ethnopharmacol. 243, 112081.

Saad, S., Ouafi, S., Chabane, D., 2016. Anti-inflammatory and acute toxicity evaluation of aqueous infusion extract obtained from aerial parts of Marrubium deserti De Noé growing in Algeria. Afr. J. Tradit., Complementary Altern. Med. 13 (1), 71-75.

Satyanarayana, P.S., Jain, N.K., Singh, A., Kulkarni, S.K., 2004. Isobolographic analysis of interaction between cyclooxygenase inhibitors and tramadol in acetic acidinduced writhing in mice. Prog. Neuro Psychopharmacol. Biol. Psychiatr. 28 (4), 641-649.

Schnitzler, P., Nolkemper, S., Stintzing, F., Reichling, J., 2008. Comparative in vitro study on the anti-herpetic effect of phytochemically characterized aqueous and ethanolic extracts of Salvia officinalis grown at two different locations. Phytomedicine 15 (1-2), 62-70.

Sekkoum, K., Cheriti, A., Taleb, S., Bourmita, Y., Belboukhari, N., 2011. Traditional phytotherapy for urinary diseases in Bechar district (south west of Algeria). Electron. J. Environ. Agric. Food Chem. 10 (8), 2616-2622.

Senol, F.S., Ślusarczyk, S., Matkowski, A., Pérez-Garrido, A., Girón-Rodríguez, F., CerónCarrasco, J.P., den-Haan, H., Peña-García, J., Pérez-Sánchez, H., Domaradzki, K., 2017. Selective in vitro and in silico butyrylcholinesterase inhibitory activity of diterpenes and rosmarinic acid isolated from Perovskia atriplicifolia Benth. and Salvia glutinosa L. Phytochemistry 133, 33-44.
Sevgi, K., Tepe, B., Sarikurkcu, C., 2015. Antioxidant and DNA damage protection potentials of selected phenolic acids. Food Chem. Toxicol. 77, 12-21.

Shahidi, F., Yeo, J., 2018. Bioactivities of phenolics by focusing on suppression of chronic diseases: a review. Int. J. Mol. Sci. 19 (6), 1573.

Simon-Arceo, K., Gonzalez-Trujano, M.E., Coffeen, U., Fernandez-Mas, R., Mercado, F., Almanza, A., Contreras, B., Jaimes, O., Pellicer, F., 2017. Neuropathic and inflammatory antinociceptive effects and electrocortical changes produced by Salvia divinorum in rats. J. Ethnopharmacol. 206, 115-124.

Sreeja, P.S., Arunachalam, K., de Oliveira Martins, D.T., da Silva Lima, J.C., Balogun, S. O., Pavan, E., Saikumar, S., Dhivya, S., Kasipandi, M., Parimelazhagan, T., 2018. Sphenodesme involucrata var. paniculata (CB Clarke) Munir.: chemical characterization, anti-nociceptive and anti-inflammatory activities of methanol extract of leaves. J. Ethnopharmacol. 225, 71-80.

Stevens, P.F., 2016. Angiosperm Phylogeny Website. Version 13. Angiosperm Phylogeny Website. Version 13.

Tamokou, J., Mbaveng, A., Kuete, V., 2017. Antimicrobial Activities of African Medicinal Spices and Vegetables, Medicinal Spices and Vegetables from Africa. Elsevier, pp. 207-237.

Tapas, A.R., Sakarkar, D., Kakde, R., 2008. Flavonoids as nutraceuticals: a review. Trop. J. Pharmaceut. Res. 7 (3), 1089-1099.

Tjølsen, A., Berge, O.-G., Hunskaar, S., Rosland, J.H., Hole, K., 1992. The formalin test: an evaluation of the method. Pain 51 (1), 5-17.

Tohma, H., Köksal, E., , Kılıç, Ö., Alan, Y., Yılmaz, M., Gülçin, I., Bursal, E., Alwasel, S., 2016. RP-HPLC/MS/MS analysis of the phenolic compounds, antioxidant and antimicrobial activities of Salvia L. species. Antioxidants 5 (4), 38.

Torres, P., Poveda, A., Jimenez-Barbero, J., Parra, J.L., Comelles, F., Ballesteros, A.O., Plou, F.J., 2011. Enzymatic synthesis of $\alpha$-glucosides of resveratrol with surfactant activity. Adv. Synth. Catal. 353 (7), 1077-1086.

Van Wyk, B.-E., Wink, M., 2018. Medicinal Plants of the World. CABI.

Walker, J.B., Sytsma, K.J., Treutlein, J., Wink, M., 2004. Salvia (Lamiaceae) is not monophyletic: implications for the systematics, radiation, and ecological specializations of Salvia and tribe Mentheae. Am. J. Bot. 91 (7), 1115-1125.

Zhu, F., Asada, T., Sato, A., Koi, Y., Nishiwaki, H., Tamura, H., 2014. Rosmarinic acid extract for antioxidant, antiallergic, and $\alpha$-glucosidase inhibitory activities, isolated by supramolecular technique and solvent extraction from Perilla leaves. J. Agric. Food Chem. 62 (4), 885-892. 